\title{
Leaf damage and density-dependent effects on six Inga species in a neotropical forest
}

Tania Brenes-Arguedas

Smithsonian Tropical Research Institute, P.O. Box 0843-03092, Balboa, Ancon Republic of Panama; brenest@si.edu

\author{
Received 29-XI-2011. Corrected 03-V-2012. Accepted 04-VI-2012.
}

\begin{abstract}
Many models have been proposed to explain the possible role of pests in the coexistence of a high diversity of plant species in tropical forests. Prominent among them is the Janzen-Connell model. This model suggests that specialized herbivores and pathogens limit tree recruitment as a function of their density or proximity to conspecifics. A large number of studies have tested the predictions of this model with respect to patterns of recruitment and mortality at different life stages, yet only a few have directly linked those density- or distance-dependent effects to pest attack. If pest-attack is an important factor in density- or distance-dependent mortality, there should be spatial heterogeneity in pest pressure. I studied the spatial distribution of leaf damage in saplings of six common Inga species (Fabaceae: Mimosoideae) in the 50ha forest dynamic plot of Barro Colorado Island, Panama. The percent leaf damage of Inga saplings was not heterogeneous in space, and the density of conspecific, congener or confamilial neighbors was uncorrelated with the observed damage levels in focal plants. One of the focal species did suffer density-dependent mortality, suggesting that spatial variation in plant performance in these species is not directly driven by leaf damaging agents. While multiple studies suggest that density-dependent effects on performance are common in tropical plant communities, our understanding of the mechanisms that drive those effects is still incomplete and the underlying assumption that these patterns result from differential herbivore attack deserves more scrutiny. Rev. Biol. Trop. 60 (4): 1503-1512. Epub 2012 December 01 .
\end{abstract}

Key words: density-dependence, herbivory, Inga, Janzen-Connell hypothesis, Panama.

One of the central problems in tropical biology has been to understand the mechanisms that permit the coexistence of so many potentially competing tree species. Many diverse mechanisms such as habitat associations and stochastic processes are probably involved in maintaining tree species coexistence (e.g., Denslow 1987, Hubbell 2001, Wright 2002). Among these, frequency- and density-dependent processes have received considerable attention (Webb \& Peart 1999, Harms et al. 2000, Hubbell et al. 2001, Chave et al. 2002, Peters 2003, Uriarte et al. 2004, Wills et al. 2006). In particular, a large number of empirical tests and theories (Wright 2002, Leigh et al. 2004, Adler \& Muller-Landau 2005) have focused on the Janzen-Connell model of species coexistence (Janzen 1970, Connell 1971). The Janzen-Connell model predicts that juvenile survival will be disfavored close to the parent tree due to the locally high herbivore abundance associated with the large crown of the adult tree or with the higher density of recruiting conspecifics.

These density- and distance-dependent predictions of the Janzen-Connell model provided clear, testable hypotheses regarding plant distribution and mortality. For that reason, there is a considerable body of literature evaluating these predictions (see reviews in: Clark \& Clark 1984, Hammond \& Brown 1998, Hyatt et al. 2003). Most studies have focused on seeds or seedlings since they are more likely to die from herbivore attack than larger plants (e.g., 
Augspurger 1984, De Steven 1994, Webb \& Peart 1999). However, folivores and pathogens can also influence the growth of larger saplings (Sullivan 2003) and a number of studies have also tested larger size classes at the community scale (Hubbell et al. 1990, Condit et al. 1992, Wills et al. 1997, Hubbell et al. 2001, Peters 2003, Uriarte et al. 2004, Comita et al. 2010). The results of the studies are quite variable among species (Hyatt et al. 2003) and also among types of predators (Hammond \& Brown 1998). However, community-level studies have shown that there is a general trend for negative density-dependence in the seed-seedling transition (Harms et al. 2000), and in the survival of seedlings, saplings and larger size classes (Peters 2003, Comita et al. 2010).

One component of the Janzen-Connell model that has not been thoroughly evaluated, is the assumption that specialized pests are the mechanism driving density-dependent effects in tree performance. Studies testing the Janzen-Connell model have typically focused on the model prediction of variation in plant performance (recruitment, growth or mortality), and the specific mechanisms affecting plant performance are seldom identified. For studies that focused on seeds, disappearance can only be attributed to predation, but seedling and sapling performance is subject to a plethora of other challenges including competition for water, nutrients or light. Thus unlike seeds, the evidence for spatial heterogeneity in seedling or sapling performance does not necessarily amount to evidence for spatial heterogeneity in pest pressure (Clark \& Clark 1984). Only a few studies have explicitly tied distance-dependent mortality to the effect of pests (e.g., Clark \& Clark 1985, Gilbert et al. 1994, Packer \& Clay 2000); and among those, the evidence indicates that soil pathogens may be more important drivers of distance-dependent seedling mortality than insect herbivores (Mangan et al. 2010, Swamy \&Terborgh 2010).

Overall, for specialized pests to drive Janzen-Connell effects they also have to meet a number of underlying assumptions: 1) Pest pressure should be driven by bottom-up effects, such that local abundance of food resources drives local herbivore populations; 2) pests should be very specialized, such that they respond to spatial distribution of only one host; and 3) pests should have low dispersal ability. If they meet these assumptions, there should be spatial heterogeneity in pest pressure, such that it matches the spatial distribution of the conspecific density. With the main exception of insect specialization, these assumptions have not been thoroughly evaluated.

With the intention of specifically test the Janzen-Connell assumption of spatial heterogeneity in pest pressure, I investigated the spatial distribution of leaf damage and mortality in saplings of six species of the genus Inga (Fabaceae: Mimosoidae). I specifically asked the following two questions: (1) is there spatial heterogeneity in the leaf damage of the focal Ingas?; and (2) are individual leaf-damage levels explained by the local density of hosts? For this, I analyzed a data set of herbivory measurements collected in the $50 \mathrm{Ha}$ Forest Dynamic Plot in Barro Colorado Island, Panama.

\section{MATERIALS AND METHODS}

Study site: The study was done in the 50ha Forest Dynamic Plot on Barro Colorado Island (BCI), Panama. In this plot all the trees larger than $1 \mathrm{~cm}$ diameter at breast height $(\mathrm{dbh})$ have been mapped and identified to species every five years since 1984 (Condit et al. 2005). BCI is a $1500 \mathrm{ha}$ artificial island in Gatun Lake, created when the Panama Canal was flooded in 1914. The plot is located on the plateau of the island at $9^{\circ} 09^{\prime} \mathrm{N}-79^{\circ} 51^{\prime} \mathrm{W}$, with an elevation of $162 \mathrm{~m}$. The climate is typical of a lowland tropical moist forest. The average daily temperature is $27^{\circ} \mathrm{C}$ and the average total yearly rainfall $2600 \mathrm{~mm}, 90 \%$ of which falls during the rainy season, from May through December. The field station is managed by the Smithsonian Tropical Research Institute and the plot by the Center for Tropical Forest Science (CTFS).

Study species: The genus Inga (Fabaceae: Mimosoideae) comprises about 300 species 
that may have radiated as recently as $2 \mathrm{Mya}$ (Pennington 1997, Richardson et al. 2001). It is widespread and abundant throughout the Neotropics, and in most communities where Inga is present, there are multiple species of the genus growing sympatrically. In the BCI 50ha plot there are 15 Inga species, which comprise $7 \%$ of the tree species and $2.2 \%$ of the total number of stems (Condit et al. 2005). I worked with the six most abundant Inga species in the plot, namely: Inga acuminata (16), I. goldmanii (25), I. marginata (58), I. nobilis (38), I. sapindoides (19) and I. umbellifera (51) where the numbers in parentheses represent the mean abundance per hectare for stems $>1 \mathrm{~cm} \mathrm{dbh}$.

Herbivory measurements: I measured percent leaf area damaged using a grid on at least three mature leaves per plant in a total of 209 saplings (roughly 35 plants per species) throughout the BCI 50ha plot (Fig. 1). All plants were juveniles smaller than $5 \mathrm{~cm}$ dbh, with foliage that could be reached by hand. I did not measure seedlings. While I did not specifically avoid gaps, most of my measurements were in the understory. These herbivory data have already been published elsewhere as species means, and other method details can be found in Brenes-Arguedas et al. (2008). While these data were not specifically collected for this analysis, their location in the mapped 50 ha plot provides a useful framework to run a spatial analysis. Most measured plants were already mapped in the plot database, and for some smaller saplings $(<1 \mathrm{~cm} \mathrm{dbh)} \mathrm{that} \mathrm{had} \mathrm{not}$ yet entered the censuses, I estimated the coordinates in the 50-ha plot using the $5 \mathrm{~m}$ quadrants.

\section{Spatial heterogeneity in leaf damage:} All data were analyzed with the R software (R Development Core Team 2009). If there was spatial heterogeneity in pest pressure I expected to find 'hot-spots' and 'cold-spots' of herbivore pressure in the 50 ha plot. Such a pattern can be detected using spatial autocorrelation analysis. This analysis tests the hypothesis that neighboring plants suffer more similar damage levels than more distant plants because they are exposed to the same local conditions of herbivore pressure. To test for spatial autocorrelation

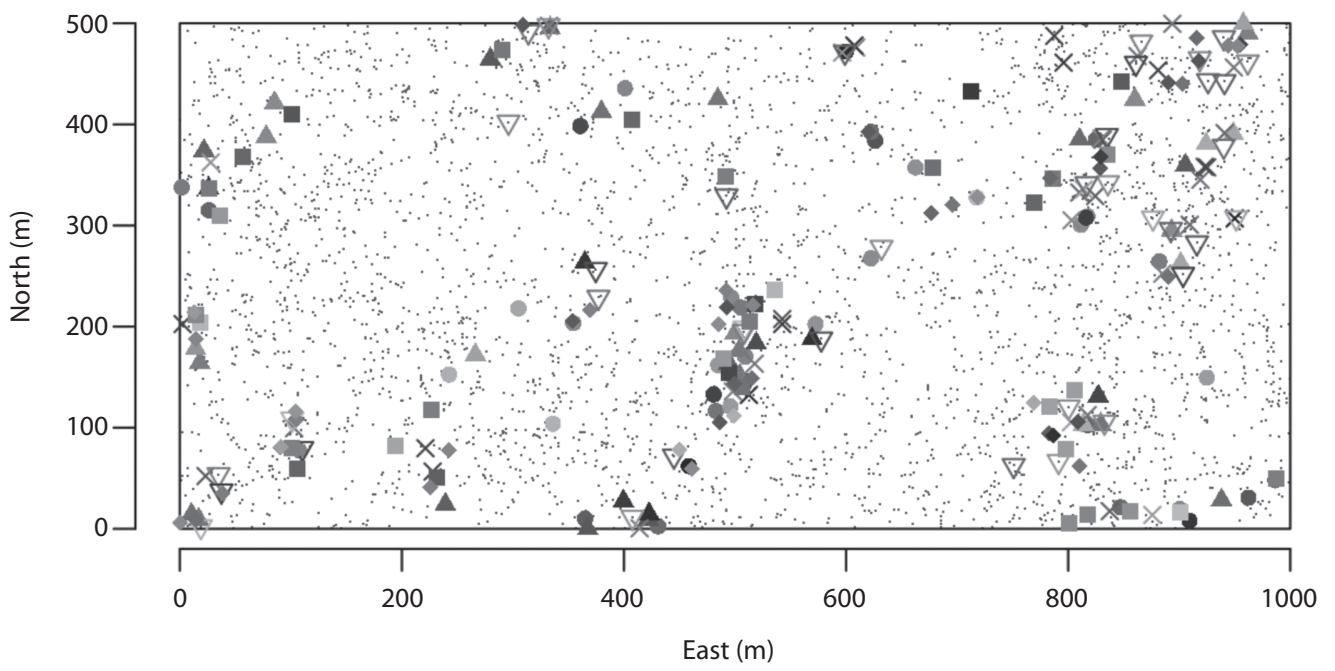

Fig. 1. Map of the 50-ha Forest Dynamics Plot in BCI showing the distribution of all Inga stems alive in the census of the year 2000 (dots). The Inga individuals for which I measured leaf damage are indicated by symbols (I. acuminata, $\bullet$ goldmanii, p; marginata, İ; nobilis, s; sapindoides, 3/4; and umbellifera, $\left.{ }^{\circledR}\right)$. For each individual leaf damage levels are indicated by a shade of gray, with darker colors indicating higher damage. 
I used the plot coordinates of the individuals for which I had damage measurements to calculate the Moran's $I$ statistic defined as:

$$
I=n \sum \sum w_{i j}\left(d_{i}-d\right)\left(d_{j}-d\right) \sum w_{i j} \sum\left(d_{i}-d\right)
$$

where $w_{i j}$ is the inverse of the linear distance between plants $i$ and $j ; d_{i}$ and $d_{j}$ their respective leaf damage levels, and $\bar{d}$ is the mean damage for all plants. $I=0$ indicates no autocorrelation and $I>0$ indicates positive autocorrelation. Because I was interested in the presence of clusters of high or low herbivory, negative autocorrelation does not have an ecological interpretation in this context. I calculated the Moran $I$ for each species individually (to test only conspecific effects), and for all Inga together (to test congener effects). I generated correlograms by grouping $w_{i j}$ into $20 \mathrm{~m}$ distance classes. I tested for significant departures from zero using Monte Carlo randomizations where the herbivory data of each sapling was randomly assigned to the position of a different sapling. The $95 \%$ confidence intervals were calculated as the percentiles from 200 randomizations.

Neighbor density estimates: To determine the local densities of neighbors, I used the plot data from the census of the year 2000 (Condit et al. 2005). I calculated density for all individuals larger than $1 \mathrm{~cm}$ dbh inside circles centered on each of the focal plants. To account for the possible use of alternative hosts in the population, I separately estimated density of conspecific, congeners, and confamilial neighbors. I estimated density as a simple count of all stems and as the sum of the basal area of the neighbors. In the count of stems all neighbors are considered equally important regardless of their size. In the sum of basal areas, larger trees, which have larger crowns and may be stronger infection sources, have more weight than smaller saplings. All densities were corrected for edge effects dividing by a parameter equal to the fraction of the circle area that falls inside the plot. This correction assumes that the distribution of trees outside the plot is the same as inside the plot.

The effect of neighbor density on leaf damage: To test for density-dependent effects on pest attack, I correlated leaf damage to the neighbor density around each of the measured focal plants using a multiple linear model $(\mathrm{R}$ ' $\mathrm{lm}$ ' procedure) of the form:

$$
\text { Damage }=\beta_{0}+\beta_{\mathrm{sp}} \cdot s p .+\beta_{g n} \cdot g n+\beta_{f m} \cdot f m
$$

where $b_{i}$ are the parameters and $s p, g n$ and fm are the corrected densities of conspecifics, congeners (not including conspecifics), or confamilials (not including congeners), respectively. Hence, the effects of congeners and confamilials are tested as additions over the effect of conspecifics. Based on the analysis by Hubble et al. (2001) I evaluated the multiple regression at 10,15 and $20 \mathrm{~m}$ radius from the focal plant, but for simplicity I showed only the results from the analysis at $15 \mathrm{~m}$ radius. Model residuals were tested for spatial autocorrelation using the 'moran.test' procedure of the 'spdep' package (version 0.4-34 by Roger Bivand \& contributors).

Density dependent mortality: To test whether the focal species suffered density dependent mortality, I tested all individuals of the focal species smaller than $5 \mathrm{~cm}$ dbh, that were alive in the 1985 census (second census; Condit et al. 2005). I included all mortality events that happened in the following 20 years until the census of 2005. I evaluated a multiple regression with the same parameters as the leaf damage regression but using the logit transformed data and binomial errors appropriate to mortality data (R ' $\mathrm{glm}$ ' procedure). Spatial autocorrelation was tested as above and when necessary I corrected for autocorrelation by adding an autocovariance distribution parameter to the model (estimated with the 'autocov_dist' function of 'spdep' package). 


\section{RESULTS}

Spatial heterogeneity in leaf damage: There was little evidence for spatial heterogeneity in herbivore pressure based on the spatial autocorrelation analysis. When analyzing each species separately, only Inga goldmanii and $I$. umbellifera had a positive Moran's I statistic, consistent with positive spatial autocorrelation in leaf damage (Moran's I: I. acuminata: -0.41 , I. goldmanii: 0.36 , I. marginata: -0.11 , I nobilis: -0.2, I. sapindoides: -0.1 , and I. umbellifera: $0.23)$. However, the correlograms showed that none of the correlation patterns significantly differed from a random distribution (Fig. 2). Similarly, when analyzing all focal Inga together as a genus, Moran's $I$ was not different from zero $(\mathrm{I}=0.0073, \mathrm{~N}=235, \mathrm{p}=0.34)$.

Effect of neighbor density on leaf damage: I found only weak evidence suggesting that neighbor density significantly explained the variation in standing leaf damage observed on the focal Inga species. For I. goldmanii, conspecific basal area at $15 \mathrm{~m}$ radius, showed a weak positive effect on leaf damage with $\mathrm{p}=0.03$ (Table 1). However, applying a Bonferroni correction that accounts for the 18 independent species $\mathrm{x}$ radius tests, significance would require $\mathrm{p}<0.003$ (even a very lax Bonferroni correction that accounts only for the three separate radius analyzed, requires $\mathrm{p}<0.017$ ). Hence, this value cannot be considered significant. Consistent with this, when the analysis was repeated for radius 10 or $20 \mathrm{~m}$ this species does not show any more effects with $\mathrm{p}<0.05$. Indeed, for all species the variation in damage at any given density was extremely large, and it is clear that some trends are driven by one individual (Fig. 3).

Density dependent mortality: For this analysis, two of the species had to be corrected for significant autocorrelation in the residuals. After correction for autocorrelation, only one of the six focal species, I. marginata,
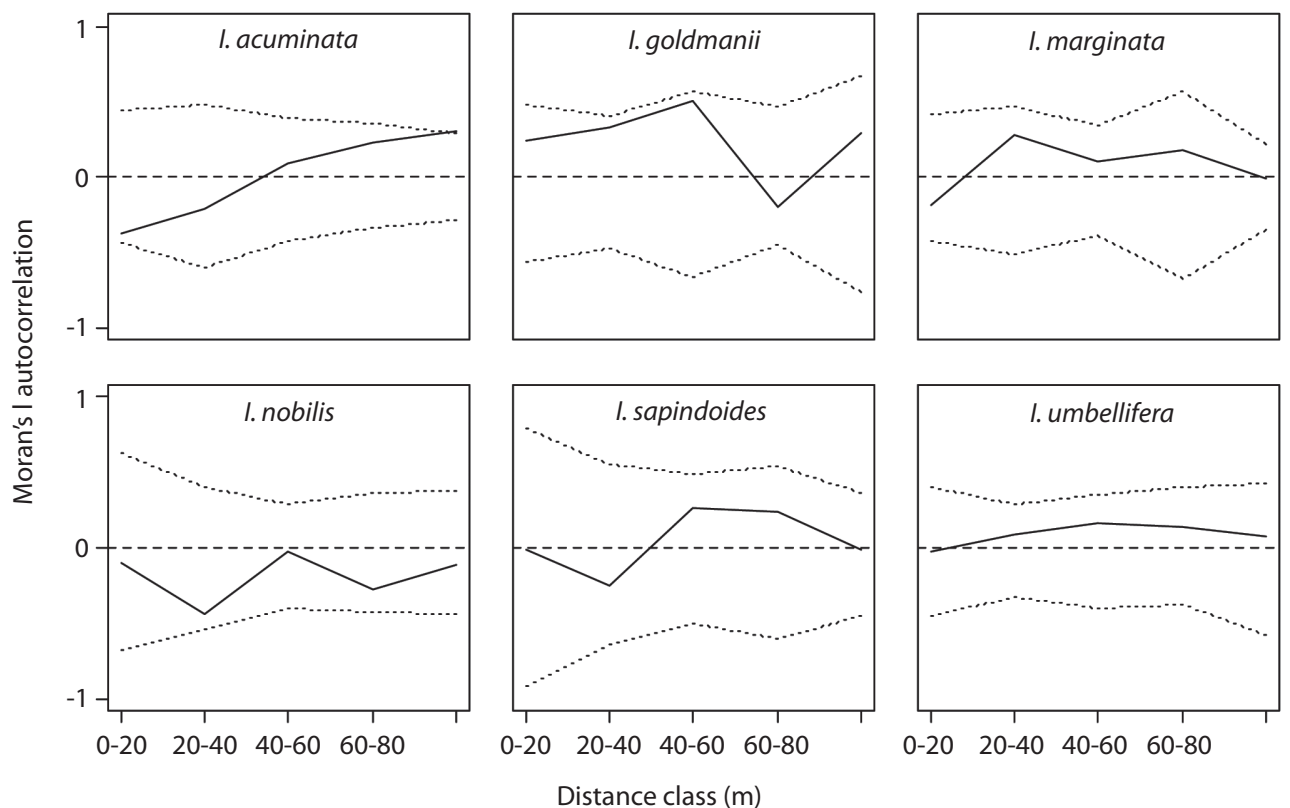

Fig. 2. Correlograms showing the Moran's $I$ statistic (solid line) as a function of distance class for the six focal Inga species. The dashed line represents zero autocorrelation and dotted lines represent Monte Carlo 95\% CI. No species differs significantly from zero. 
TABLE 1

Parameter estimates for the multiple regressions that explain leaf damage and mortality as a function of the density of conspecific (sp), congeners (gn) and confamilial (fm) neighbors within a $15 \mathrm{~m}$ radius

\begin{tabular}{|c|c|c|c|c|c|c|c|}
\hline & \multirow{2}{*}{ Species } & \multicolumn{3}{|c|}{ Herbivory } & \multicolumn{3}{|c|}{ Mortality } \\
\hline & & $\beta_{\mathrm{sp}}$ & $\beta_{\mathrm{gn}}$ & $\beta_{\mathrm{fm}}$ & $\beta_{\mathrm{sp}}$ & $\beta_{\mathrm{gn}}$ & $\beta_{\mathrm{fm}}$ \\
\hline \multirow{6}{*}{ 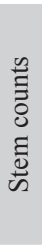 } & I. goldmanii & 0.019 & -0.001 & 0.002 & 0.094 & -0.002 & -0.014 \\
\hline & I. marginata & 0.029 & 0.006 & 0.004 & $0.076^{* *}$ & 0.007 & -0.005 \\
\hline & I. nobilis & -0.032 & -0.008 & 0.001 & -0.030 & -0.028 & -0.011 \\
\hline & I. acuminata & -0.002 & 0.009 & -0.004 & 0.063 & 0.001 & 0.023 \\
\hline & I. sapindoides & 0.001 & -0.002 & -0.002 & -0.134 & 0.010 & -0.016 \\
\hline & I. umbellifera & 0.007 & -0.002 & $-0.007 *$ & 0.020 & -0.007 & -0.005 \\
\hline \multirow{6}{*}{ 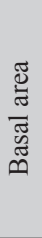 } & I. goldmanii & $0.125^{*}$ & 0.008 & 0.000 & 8.598 & -4.259 & -0.085 \\
\hline & I. marginata & -0.007 & -0.007 & 0.001 & 1.392 & -1.066 & 0.166 \\
\hline & I. nobilis & -0.024 & -0.002 & -0.001 & -3.246 & -1.789 & -0.231 \\
\hline & I. acuminata & -0.015 & 0.016 & $0.001 *$ & 7.953 & 4.278 & -0.223 \\
\hline & I. sapindoides & 0.010 & 0.003 & 0.000 & 31.835 & 2.790 & -0.396 \\
\hline & I. umbellifera & 0.136 & 0.004 & 0.000 & 51.481 & -2.529 & -0.246 \\
\hline
\end{tabular}

Densities were evaluated both as count of stems and sum of basal areas of stems. Parameters that improve the model are indicated with * $(\mathrm{p}<0.05)$ and $* *(\mathrm{p}<0.003$, significant based on a Bonferroni correction $)$.
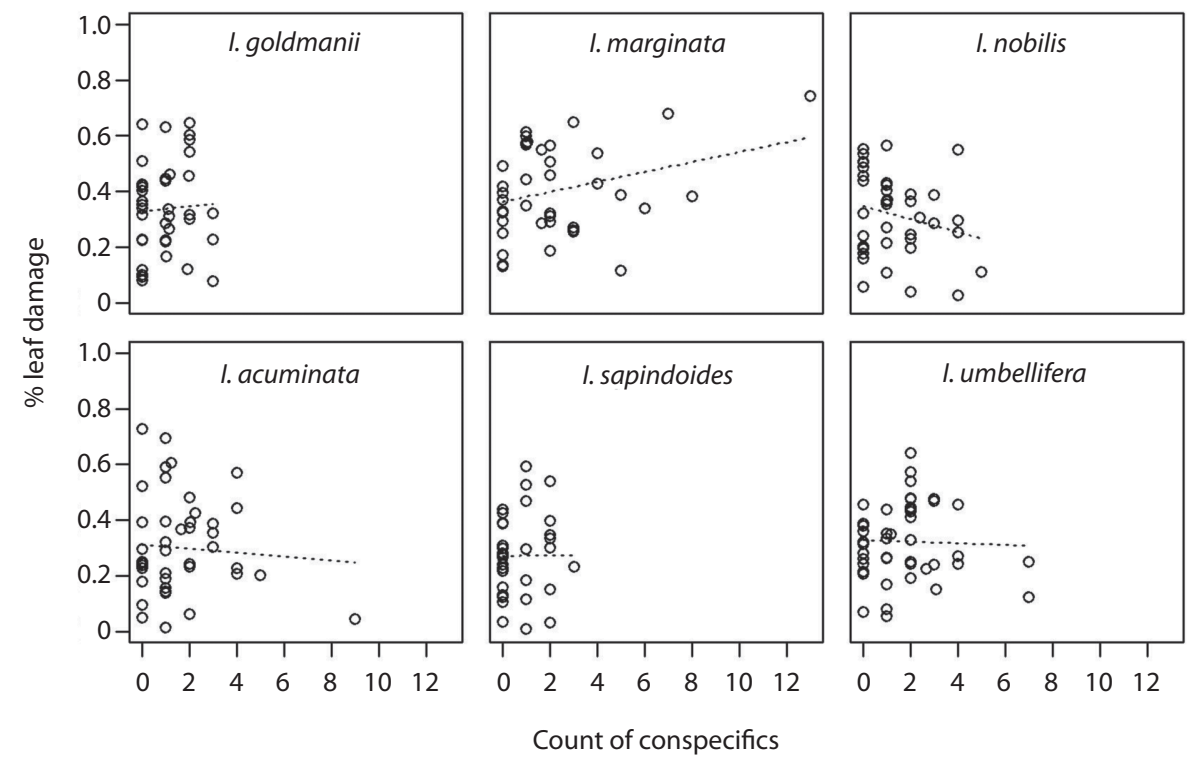

Fig. 3. Scatterplots showing the percent damage for all individuals as a function of the count of conspecific neighbors within a $15 \mathrm{~m}$ radius. Dotted lines represent the best fit for the univariate linear model. None of the regressions is significant at $\mathrm{a}=0.05$. 
showed significant evidence of density dependent mortality ( $\mathrm{p}=0.0001$, Table 1$)$. This result is strongly significant even after a conservative Bonferroni correction and, more over, remained significant when the model was evaluated at different radii.

Including the presence of congeners or confamilials did not improve any of the herbivory or mortality models evaluated (Table 1 ). For I. umbellifera and I. acuminata the parameter for the effect of confamilial density on damage had $p<0.05$. This value is not significant using the Bonferroni corrections described above, but also, conspecific and congener density did not correlate with damage, and in this analysis the role of confamilial density alone has little ecological significance. Consistent with this, the $\mathrm{p}$ value was also $>0.05$ when evaluated at a different radii.

\section{DISCUSSION}

In this study I evaluated one of the assumptions of the Janzen-Connell model using a novel approach and the statistical methodology normally used in spatially explicit population level studies of density-dependent mortality. My results suggest that the Janzen-Connell assumption of spatial heterogeneity in herbivore pressure does not apply to the Inga study species with respect to leaf damaging agents.

While I found a few trends in the spatial structure of Inga leaf damage, in general these were not very strong. Hence, the spatial analyses of leaf damage were, at best, inconclusive. I found no evidence that spatial autocorrelation in leaf damage was significantly different from random. Also, while there were a few correlations with $\mathrm{p}<0.05$ between neighbor density and leaf damage, these did not hold when the analysis conditions were changed (different radii or different subsets of stems). Furthermore, this $\mathrm{p}$ value is not significant if corrections for multiple testing (Type II error) are taken into account. Hence, these data provide little evidence that there is spatial aggregation in leaf damaging agents. It is possible that the herbivory data I used here were not collected broadly enough in the 50 ha plot to maximize the power to evaluate this hypothesis. However, for the analysis of density-dependent mortality I used the complete plot data set and 20 years of mortality data. Yet, only one of the six study species, I. marginata, showed clear evidence of density-dependent mortality. This second analysis supports the absence of spatial heterogeneity in leaf damage for my study species.

A few other studies have found distancedependent effects of herbivory using methodologies that focus on only a few adult trees (Clark \& Clark 1985, Blundell \& Peart 1998, Barone 2000). Unlike those studies, here I focused on density-dependence and used a methodology based on analysis of spatial dynamics at the population scale. Hence, the different results might be due to the different methodology or to the different set of species used. However, a number of recent studies that have experimentally evaluated herbivore pressure, found little evidence that insect herbivores drove distancedependent effects (Mangan et al. 2010, Swamy \&Terborgh 2010). As my measurements were limited to leaf damage, my results might indeed be consistent with those studies. Indeed, pathogens often attack other parts of the plant and cause density-dependent mortality (Gilbert et al. 1994). This distinction might explain why I. marginata, the only species that suffered density-dependent mortality, did not show clear evidence of density-dependent leaf damage.

Why would the other Inga species not suffer density-dependent mortality or damage? There are two factors that might explain the absence of these effects. The first is that for pest pressure to increase in a density-dependent manner, as is assumed in the Janzen-Connell model, local herbivore pressure should be driven by bottom-up controls, in other words, by resource availability in the form of host density. However, top-down effects from predators can also impose controls on herbivore populations (Hunter et al. 1997). These may be especially important in my Inga study system, as species 
in the genus Inga have nectaries on the leaves that attract ant defenders (Koptur 1984), thus actively involving top-down interactions in their defense. If ants do respond to the density of plants with nectaries, it is possible that the same density-dependent effects that might locally increase herbivore abundance could also increase the abundance of defensive ants. This could neutralize positive density-dependence resulting from herbivore attack.

It is also possible that pest attack becomes spatially random if herbivores in the population have a complex combination of hosts. The Janzen-Connell model assumes that densitydependent effects occur at the species level due to high specialization of tropical herbivores. A sizable body of literature has discussed the specialization levels of tropical herbivores (Janzen 2003, Novotny \& Basset 2005, Dyer et al. 2007, Novotny et al. 2007), and such high specialization is not necessarily the norm in complex herbivore assemblages typical of tropical species (Basset et al. 1996). Indeed, high specialization is not the norm in my study system in particular (Kursar et al. 2006). I tried to account for this by testing for the effects of congeners or confamilials on leaf damage and mortality, but found that these did not significantly influence density-dependence. It is possible that the combination of potential hosts that could influence pest pressure is more complex than what I used here. If so, this would further support the absence of spatial heterogeneity in leaf damage.

Community-wide analyses have shown that density-dependent effects on mortality are pervasive but they are not present for all the species. For example, in two 50ha plots in Pasoah, Malaysia and BCI, Panama, only 46 and $47 \%$ of the species analyzed suffered positive density-dependent mortality (Peters 2003). Here I took a closer look at the spatial dynamics of six common Inga species to argue that our understanding of the mechanisms that might mediate these effects is still too incomplete. Looking at the characteristics of the species that do not suffer densitydependent mortality may provide valuable insight into the mechanisms that mediate this effect. For example, the absence of densitydependent mortality for some species might be due to lack of analytical power or due to the absence of heterogeneity in pest attack. Studies might have to integrate the spatial dynamics of different kinds of pests, such as pathogens, insects or mammals; the dynamics of complex herbivore assemblages; the effect of predators; and the types of plant defensive strategies. While this is not an easy task, this insight will provide a valuable understanding of the role of plant-pest interactions in the dynamics of tropical forests.

\section{ACKNOWLEDGMENTS}

This research was funded by a Center for Tropical Forest Science (CTFS) research fellowship and NSF DEB-0407653. I thank the Smithsonian Tropical Research Institute for permits and logistic support; and the CTFS, Richard Condit, Stephen Hubble, Robin Foster, Suzanne Lao and Rolando Perez for making the BCI plot census data available for researchers. I thank Fred Adler and Richard Condit for valuable comments on the data analysis, Lissy Coley and two anonymous reviewers for comments on the manuscript.

\section{RESUMEN}

Se han propuesto muchos modelos para explicar la coexistencia de una alta diversidad de especies de árboles en bosques tropicales. Prominente, entre estos modelos es el de Janzen-Connell, que sugiere que los herbívoros especialistas limitan la colonización de árboles en función de la densidad o proximidad de con-específicos. Si este efecto es en realidad el resultado de ataque por herbívoros, debiera haber heterogeneidad espacial en la herbivoría. Aquí se evalúa esta hipótesis estudiando la distribución espacial de la herbivoría en juveniles de seis especies comunes de Inga (Fabaceae: Mimosoideae) en la parcela de 50ha de la Isla de Barro Colorado, en Panamá. Análisis de auto-correlación espacial no mostraron heterogeneidad en la herbivoría de estas especies, y la densidad local de con-específicos, congéneres o confamiliares no se correlacionó con la herbivoría de las plantas estudiadas. Solo una de las especies de estudio sufrió mortalidad densidad-dependiente en 20 años de censos. Aunque muchos estudios han demostrado que los efectos densidad-dependientes en la mortalidad 
de las plantas son comunes en bosques tropicales, nuestro entendimiento de los mecanismos que causan esos efectos es aún limitado, y la suposición de que estos resultan de heterogeneidad espacial en el ataque de herbívoros merece más escrutinio.

Palabras clave: densidad-dependencia, herbivoría, Inga, hipótesis Janzen-Connell, Panamá.

\section{REFERENCES}

Adler, F.R. \& H.C. Muller-Landau. 2005. When do localized natural enemies increase species richness? Ecol. Lett. 8: 438-447.

Augspurger, C.K. 1984. Seedling survival of tropical tree species: Interactions of dispersal distance light-gaps and pathogens. Ecology 65: 1705-1712.

Barone, J.A. 2000. Comparison of herbivores and herbivory in the canopy and understory for two tropical tree species. Biotropica 32: 307-317.

Basset, Y., G.A. Samuelson, A. Allison \& S. Miller. 1996. How many species of host-specific insects feed on a species of tropical tree? Bio. J. Linn. Soc. 59: 201-216.

Blundell, A.G. \& D.R. Peart. 1998. Distance-dependence in herbivory and foliar condition for juvenile Shorea trees in Bornean dipterocarp rain forest. Oecologia 117: $151-160$.

Brenes-Arguedas, T., P.D. Coley \& T.A. Kursar. 2008. Divergence and diversity in the defensive ecology of Inga at two Neotropical sites. J. Ecol. 96: 127-135.

Chave, J., H.C. Muller-Landau \& S.A. Levin. 2002. Comparing classical community models: Theoretical consequences for patterns of diversity. Am. Nat. 159: $1-23$.

Clark, D.A. \& D.B. Clark. 1984. Spacing dynamics of a tropical rain forest tree: Evaluation of the JanzenConnell model. Am. Nat. 124: 769-788.

Clark, D.B. \& D.A. Clark. 1985. Seedling dynamics of a tropical tree: Impacts of herbivory and meristem damage. Ecology 66: 1884-1892.

Comita, L.S., H.C. Muller-Landau, S. Aguilar \& S.P. Hubbell. 2010. Asymmetric Density Dependence Shapes Species Abundances in a Tropical Tree Community. Science 329: 330-332.

Condit, R., S.P. Hubbell \& R.B. Foster. 1992. Recruitment near conspecific adults and the maintenance of tree and shrub diversity in a Neotropical forest. Am. Nat. 140: 261-286.

Condit, R., S.P. Hubbell \& R.B. Foster. 2005. Barro Colorado forest census plot data. Center for Tropical Forest Science, Smithsonian Tropical Research
Institute, Panama. (Available online http://ctfs.si/edu/ datasets/bci).

Connell, J.H. 1971. On the role of natural enemies in preventing competitive exclusion in some marine animals and in rain forest tree, p. 298-312. In P.J. de Boer \& G. R. Gradwell (eds.). Dynamics of populations. Pudoc, Wageningen, Holland.

De Steven, D. 1994. Tropical tree seedling dynamics: Recruitment patterns and their population consequences for three canopy species in Panama. J. Trop. Ecol. 10: 369-383.

Denslow, J.S. 1987. Tropical rainforest gaps and tree species diversity. Ann. Rev. Ecol. Syst. 18: 431-451.

Dyer, L.A., M.S. Singer, J.T. Lill, J.O. Stireman, G. Gentry, R.J. Marquis, R.E. Ricklefs, H.F. Greeney, D.L. Wagner, H.C. Morais, I.R. Diniz, T.A. Kursar \& P.D. Coley. 2007. Host specificity of Lepidoptera in tropical and temperate forests. Nature 448: 696-699.

Gilbert, G.S., S.P. Hubbell \& R.B. Foster. 1994. Density and distance-to-adult effects of a canker disease of trees in a moist tropical forest. Oecologia 98: 100-108.

Hammond, D.S. \& V.K. Brown. 1998. Disturbance, phenology, and life history characteristics: Factors influencing distance/density-dependent attack on tropical seeds and seedlings, p. 51-78. In D.M. Newberry, H.H.T. Prins \& N.D. Brown (eds.). Dynamics of tropical communities. Blackwell, Oxford, England.

Harms, K.E., S.J. Wright, O. Calderón, A. Hernández \& E.A. Herre. 2000. Pervasive density-dependent recruitment enhances seedling diversity in a tropical forest. Nature 404: 493-495.

Hubbell, S.P., R. Condit \& R.B. Foster. 1990. Presence and absence of density dependence in a Neotropical tree community. Philosophical Transactions. Biological Sciences 330: 269-282.

Hubbell, S.P. 2001. The unified neutral theory of biodiversity and biogeography. Princeton University, Princeton, USA.

Hubbell, S.P., J.A. Ahumada, R. Condit \& R.B. Foster. 2001. Local neighborhood effects on long-term survival of individual trees in a Neotropical forest. Ecol. Res. 16: 859-875.

Hunter, M.D., G.C. Varley \& G.R. Gradwell. 1997. Estimating the relative roles of top-down and bottom-up forces on insect herbivore populations: A classic study revisited. Proc. Natl. Acad. Sci. USA 94: 9176-9181.

Hyatt, L.A., M.S. Rosenberg, T.G. Howard, G. Bole, W. Fang, J. Anastasia, K. Brown, R. Grella, K. Hinman, J.P. Kurdziel \& J. Gurevitch. 2003. The distance dependence prediction of the Janzen-Connell hypothesis: A meta-analysis. Oikos 103: 590-602.

Janzen, D.H. 1970. Herbivores and the number of tree species in tropical forests. Am. Nat. 104: 501-528. 
Janzen, D.H. 2003. How polyphagous are Costa Rican dry forest Saturniid caterpillars?, p. 369-379 In Y. Basset, R. Kitching, S. Miller \& V. Novotny (eds.). Arthropods of Tropical Forests: Spatio-Temporal Dynamics and Resource Use in the Canopy. Cambridge University, Cambridge, United Kingdom.

Koptur, S. 1984. Experimental evidence of defense of Inga (Mimosoideae) saplings by ants. Ecology 65: 1787-1793.

Kursar, T.A., B.T. Wolfe, M.J. Epps \& P.D. Coley. 2006. Food quality, competition, and parasitism influence feeding preference in a Neotropical Lepidopteran. Ecology 87: 3058-3069.

Leigh, E.G., P. Davidar, C.W. Dick, J.P. Puyravaud, J. Terborgh, H. ter Steege \& S.J. Wright. 2004. Why do some tropical forests have so many species of trees? Biotropica 36: 447-473.

Mangan, S.A., S.A. Schnitzer, E.A. Herre, K.M.L. Mack, M.C. Valencia, E.I. Sanchez \& J.D. Bever. 2010. Negative plant-soil feedback predicts tree-species relative abundance in a tropical forest. Nature 466: 752-755.

Novotny, V. \& Y. Basset. 2005. Review - Host specificity of insect herbivores in tropical forests. Proc. R. Soc. Lond. Biol. Sci. 272: 1083-1090.

Novotny, V., S. Miller, J. Hulcr, R.A.I. Drew, Y. Basset, M. Janda, G.P. Setliff, K. Darrow, A.J.A. Stewart, J. Auga, B. Isua, K. Molem, M. Manumbor, E. Tamtiai, M. Mogia \& G.D. Weiblen. 2007. Low beta diversity of herbivorous insects in tropical forests. Nature 448: 692-695.

Packer, A. \& K. Clay. 2000. Soil pathogens and spatial patterns of seedling mortality in a temperate tree. Nature 404: 278-281.

Pennington, T.D. 1997. The genus Inga Botany. The Royal Botanic Gardens, Kew, London.

Peters, H.A. 2003. Neigbor-regulated mortality: the influence of positive and negative density dependence on tree populations in species-rich tropical forests. Ecol. Lett. 6: 757-765.
R Development Core Team. 2009. R: A language and environment for statistical computing. R Foundation for Statistical Computing, Vienna, Austria. (Available online http://www.R-project.org).

Richardson, J.E., T.D. Pennington, R.T. Pennington \& P.M. Hollingsworth. 2001. Rapid diversification of a species-rich genus of Neotropical rain forest tree. Science 293: 2242-2245.

Sullivan, J.J. 2003. Density-dependent shoot-borer herbivory increases the age of first reproduction and mortality of Neotropical tree saplings. Oecologia 136: 96-106.

Swamy, V. \& J.W. Terborgh. 2010. Distance-responsive natural enemies strongly influence seedling establishment patterns of multiple species in an Amazonian rain forest. J. Ecol. 98:1096-1107.

Uriarte, M., R. Condit, C.D. Canham \& S.P. Hubbell. 2004. A spatially explicit model of sapling growth in a tropical forest: Does the identity of neighbors matter? J. Ecol. 92: 348-360.

Webb, C.O. \& D.R. Peart. 1999. Seedling density dependence promotes coexistence of Bornean rain forest trees. Ecology 80: 2006-2017.

Wills, C., R. Condit, R.B. Foster \& S.P. Hubbell. 1997. Strong density- and diversity-related effects help to maintain tree species diversity in a Neotropical forest. Proc. Natl. Acad. Sci. USA 94: 1252-1257.

Wills, C., K.E. Harms, R. Condit, D. King, J. Thompson, F.L. He, H.C. Muller-Landau, P. Ashton, E.C. Losos, L. Comita, S.P. Hubbell, J.V. LaFrankie, S. Bunyavejchewin, H.S. Dattaraja, S. Davies, S. Esufali, R.B. Foster, N. Gunatilleke, S. Gunatilleke, P. Hall, A. Itoh, R. John, S. Kiratiprayoon, S.L. de Lao, M. Massa, C. Nath, N.S.B.M. Noor, A.R. Kassim, R. Sukumar, H.S. Suresh, I.F. Sun, S. Tan, T. Yamakura \& E. Zimmerman. 2006. Nonrandom processes maintain diversity in tropical forests. Science 311: 527-531.

Wright, S.J. 2002. Plant diversity in tropical forests: A review of mechanisms of species coexistence. Oecologia 130: 1-14. 